\title{
Jobotifetime
}

\section{Preserving our cultural heritage, one MSIS at a time}

f you'd like nothing better than to prepare the next generation of conservators to juggle responsibilities as diverse as paper conservation, integrated pest management, HVAC, and disaster recovery, then being a conservation educator might be your job of a lifetime. Karen Pavelka is a lecturer and conservator at the University of Texas-Austin School of Information in the Kilgarlin Center for Preservation of the Cultural Record.

\section{The gods must be laughing}

Early in the interview, I asked Pavelka what had led her to become a paper conservator. She chuckled and replied, "I had no intention of being a paper conservator. It was a fluke, the gods laughing at me. While I

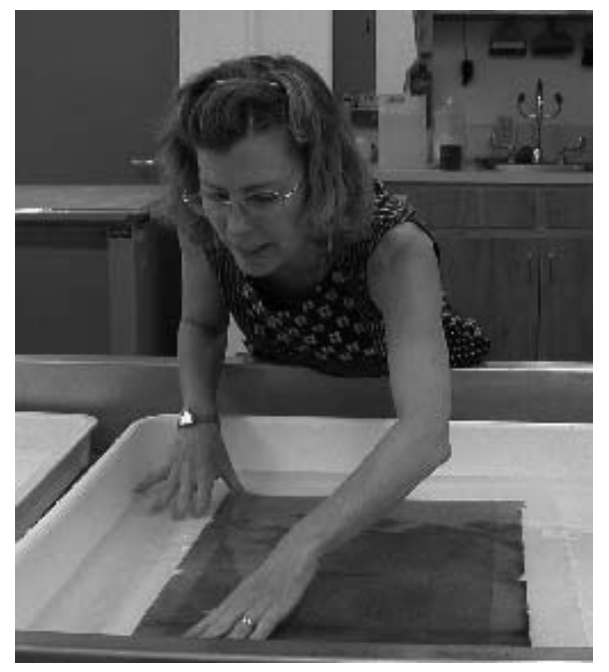

Karen Pavelka, lecturer and conservator at the University of Texas-Austin School of Information, at work.

\section{The hard life of the Texas Declaration for Independence}

When I inquired about the most interesting piece she had ever worked on, Pavelka answered without hesitation that it was when she had treated two copies of the Texas Declaration for Independence. "They were over in the University of Texas Center for American History. Both copies had been printed on the same good quality paper when they were first made, but both had led hard lives. One of them was dark brown and held together with packing tape. It had probably been next to something very acidic or in very poor storage. The project was fascinating but a little scary."

"It was fun to be able to work on it with my [then] teaching assistant Rebecca was studying for my master's at Columbia, what I really wanted to do was work with circulating collections in a large university library.

"For my internship, one of my advisors encouraged me to come down here to Texas to work at the conservation lab at the [Harry] Ransom Center. I thought I was going to work in the book lab, but I ended up working in the paper lab. It was just life that steered me in the direction of paper conservation."
Elder, who was at the end of her course of studies. While she was at a very mature point as a student, she was still facing that transition between student and conservator. The treatment was taxing as far as the level of skills required, yet one of those gratifying projects because you know how important it

Danianne Mizzy is assistant head of the Engineering Library at the University of Pennsylvania. Have an idea for a "Job of a Lifetime" story? E-mail: danianne@seas. upenn.edu. 
is to the history of the State of Texas. And a very satisfying result is always nice."

\section{Grace under pressure}

Among the qualities Pavelka mentioned as important in a conservator were tenacity and keeping a cool head. "One of the things we do is responding to disasters - going into a library that's under two feet of water and trying to pull out as much of the collection as you can. Being able to focus on 'This is the task and the rest of my life is on hold,' that sort of tenacity. It's astonishing, but it always seems to happen on a holiday or at night. I've spent several Christmas Eves mopping up floods."

"You also need to have the ability to put your emotions on hold when something goes wrong. When you're doing conservation treatment, at some point you're going to make a mistake and you need to be able to concentrate 100 percent of your intellectual abilities on solving the problem. When you have a piece of paper under water and you first see that ink starting to move, even though you've tested it as far as you can possibly

\section{Lecturer and conservator}

Where: University of Texas-Austin School of Information

For more information, visit: www.ischool.utexas.edu/kilgarlin /about.php
"Teaching is fantastic, I just love it. I teach classes in materials studies, in paper conservation treatment, and the protection and care of records materials. I started teaching part time, just one lab class every semester. It was a very intense experience. The students in this program have always been high caliber, dedicated people who are eager to let you push them as far as you possibly can. They already have the hand skills. (You need an extreme amount of physical control in a field like this, so that when you pick a little piece of tissue and put it down, it's going to end up where you want it to go.) Interestingly, when people are coming into this field they assume it's the level of hand skills that is going to define how good they are. In fact, it's judgment and a breadth of knowledge which will actually make you a conservator rather than a technician. The intellectual challenge of trying to discover what the material in front of you is and what all the subtleties of each individual project are. Most of the treatment I do now is pushing my students into doing treatment." test it with every means you have, you need to pull into play everything you know about that ink. Is it dye-based or is it pigment-based, because that's going to effect how you're going to remove it from the bath and whether you're going to use a fast method or slow method to dry it, a fair amount of pressure or no pressure. You're pulling in all those bits of knowledge because your obligation is to the artifact. At the same time, what you want to do is run into the bathroom, cry, and say 'I never should have gotten into the field and by the way, is it still too late to be a waitress?' You have to have that emotional detachment, the ability to focus on what's important and then fall apart later."

\section{The next generation}

When I asked Pavelka to talk about her move from practitioner to teacher, she exclaimed,

\section{There's nothing better}

Pavelka is passionate about being a conservator. "It's so gratifying, being able to help maintain the cultural heritage, knowing you're having an effect on how long things are going to last and be available to people." And equally so about being an educator. "The students are the rewarding part. Seeing the intensity of their experience here, seeing how diligently they work, how seriously they take the profession. Their ideas are just wonderful. Keeping up with alumni and hearing about how they're becoming forces in the field and the innovations that they are bringing. My goal as an educator is for my students to be better and smarter than I am. When you see that happening, there's nothing better. You just can't beat it."

I don't think you can beat a teacher with Pavelka's gifts. 